\title{
PENGEMBANGAN BUKU AJAR PADA MATA KULIAH EKOLOGI TUMBUHAN MELALUI INVENTARISASI TANAMAN OBAT DI SUKU SEMENDO KECAMATAN WAY TENONG LAMPUNG BARAT
}

\author{
Rasuane Noor ${ }^{1}$ \\ Triana Asih ${ }^{2}$ \\ ${ }^{1,2}$ Pendidikan Biologi FKIP Universitas Muhammadiyah Metro \\ E-mail: rasuanenoor@gmail.com,asih.triana@yahoo.com
}

\begin{abstract}
The use of traditional medicine in Indonesia has been going on since thousands of years ago before modern medicine invented and marketed. One impact of the development of science and technology, many people switch from traditional treatment that uses natural ingredients to medicines ready for consumption such as drug tablets, capsules and the like. so that traditional medicines were handed down from ancestors gradually abandoned over time the impact of information on drugs will be lost. So with an inventory of medicinal plants in the tribe Semendo, District Way Tenong West Lampung has done very importantly to be informed as early as possible one of them is the development of teaching materials. Teaching material is any material (whether information, tools and text) are arranged systematically, the figures show full of competencies to be mastered and used learners in the learning process with the aim of planning and review of the implementation of learning. teaching materials indispensable in the learning process because it can help teachers and students. This type of research is research and development $(R \& D)$. In this study, which will be the object of research is charged ecology textbook traditional medicinal plants. charged ecology textbook traditional medicinal plants contain materials Plant Ecology for students of biology education VII semester. Textbooks charged ecology of medicinal plants in the tribe Semendo, District Way Tenong West Lampung in plant ecology leaming appropriate to use well-tested by expert validation of design and materials. Results textbook manufacture of medicinal plants in the tribe Semendo, District Way Tenong West Lampung charged medicinal plant ecology in plant ecology study tested the practicality of biology education through student assessment Muhammadiyah University Metro VII semester of 2016. Textbooks charged ecology of medicinal plants in the tribe Semendo, District Way Tenong West Lampung effectively used in plant ecology learning through t-test that the average student learning outcomes through the provision of medicinal plants textbooks more than the average student results through the conventional learning process.
\end{abstract}

Kata Kunci: obat tradisional, buku ajar, ekologi tu mbuhan

Berkembangnya ilmu pengetahuan dan teknologi mendorong berbagai penelitian diberbagai bidang semakin gencar termasuk dibidang biologi dan kesehatan. Tentunya dalam perkembangan tersebut memiliki dampak positif dan negatif. Salah satu dampak berkembangnya ilmu pengetahuan dan tehnologi, banyak masyarakat beralih dari pengobatan secara tradisonal yang menggunakan bahan-bahan alami ke obat-obatan yang siap konsumsi seperti obat tablet, kapsul dan sejenisnya. sehingga obatobatan tradisional yang diwariskan turun temurun dari nenek moyang sedikit demi sedikit ditinggalkan yang dampak lama kelamaan informasi 
tentang obat-obatan tersebut akan hilang. Penggunaan obat tradisional di Indonesia sudah berlangsung sejak ribuan tahun yang lalu, sebelum obat modern ditemukan dan dipasarkan.

Suku semendo sudah sejak dahulu menempati daerah dataran tinggi dan Pegunungan di sekitar kawasan Pegunungan Bukit Barisan Selatan. Masyarakat semendo merupakan komunitas adat yang sebagian besar beraktivitas bercocok tanam dan berkebun. Ditinjau dari dukungan terhadap ekologi tumbuhan pada suku semendo sangat arif dalam pengelolah dan pemanfaatan sumber daya alam. Kearifan lokal tersebut terlihat pada saat pemilihan lahan baru dan membuka kawasan hutan untuk berkebun, masyarakat sadar bahwa setelah membuka kebun, mereka akan menanam kembali tanaman pohon untuk tetap menjaga kondisi kebun yang memiliki fungsi seperti hutan (Iskandar, 2003).

Sebelum

berkembangnya teknologi dan pengobatan modern, masyarakat selalu menggunakan bahan alami langsung dari alam sebagai obat, terutama jenis tumbuhan yang dipercaya mampu mengobati penyakitpenyakit yang diderita ketika itu. Pengetahuan obat tradisional tersebut secara perlahan akan menghilang karena masyarakat sudah tidak mengaplikasikan dalam kehidupan sehari-hari. Obat-obat yang digunakan tercatat meliputi 165 spesies dari 65 Famili tumbuhan obat (Noor dan Zen, 2015). Penelitian dan pengembangan obat tradisonal serta pendokumentasian dan database tanaman obat di Indonesia sangat penting sebagai informasi dasar untuk masyarakat sesuai dengan Keputusan Menteri Kesehatan Repubrik Indonesia tahun 2007 tentang Kebijaksanaan Obat Tradisional Indonesia. Selain itu juga erat kaitannya pelastarian etnobotani, penyelamatan pengetahuan tradisional dan kearifan masyarakat lokal. pengetahuan tersebut sangat berharga sebagai sebuah kekayaan ilmiah tradisional yang bis a memperkaya pengetahuan ilmiah modern nantinya. Sehingga dengan menginventarisasi tanaman obat di suku Semende Kecamatan Way Tenong Lampung Barat yang telah dilakukan sangat penting untuk diinformasikan sedini mungkin salah satunya adalah dengan pengembangan bahan ajar.

$$
\text { Menurut Depdiknas (2008) }
$$

bahan ajar adalah salah satu sumber belajar. Bahan ajar merupakan segala bahan (baik informasi, alat maupun teks) yang disusun secara sistematis, yang menampilkan sosok utuh dari kompetensi yang akan dikuasai peserta didik dan digunakan dalam proses pembelajaran dengan tujuan perencanaan dan penelaahan implementasi pembelajaran. Adapun fungsi bahan ajar adalah: 1) Pedoman bagi Guru yang akan mengarahkan semua aktivitasnya dalam proses pembelajaran, sekaligus merupakan substansi kompetensi yang seharusnya diajarkan kepada siswa. 2) Pedoman bagi Siswa yang akan mengarahkan semua aktivitasnya dalam proses pembelajaran, sekaligus merupakan substansi kompetensi yang seharusnya dipelajari/dikuasainya. 3) Alat evaluasi pencapaian/ penguasaan hasil pembelajaran. Berdasarkan fungsi tersebut dapat disimpulkan bahwa bahan ajar sangat diperlukan dalam proses pembelajaran karena dapat membantu guru maupun siswa. Oleh karena itu, untuk membekali pengetahuan bagi calon tenaga pendidik / guru lulusan UM Metro, peneliti akan mengembangkan buku ajar mata kuliah ekologi tumbuhan khususnya pada pokok bahasan keberlanjutan produksi tanaman dan sub bahasan etnobotani tanaman obat. 
Pengetahuan tanaman obat tradisonal dan kembali ke alam / organik di masyarakat perlu digalakan kembali salah satunya melalui pendidikan ekologi tumbuhan. Mahasiswa pendidikan biologi sebagai calon tenaga pendidik perlu dibekali pengetahuan tentang ekologi tumbuhan dengan pemahaman potensi lokal (pendekatan saintific approach). Fakta di masyarakat sudah banyaknya tidak mengerti dan paham berbagai jenis tumbuh tumbuhan obat tradisional sehingga dengan penambahan materi tentang tanaman obat dalam materi pembelajaran sangat penting untuk dibuat.

Tujuan dari penelitian ini adalah untuk Mendeskripsikan hasil pembuatan buku ajar bermuatan ekologi tanaman obat pada pembelajaran ekologi tumbuhan.

1. Mengetahui Kelayakan buku ajar bermuatan ekologi tanaman obat pada pembelajaran ekologi tumbuhan.

2. Mengetahui praktikalitas dan efektivitas buku ajar bermuatan ekologi tanaman obat pada pembelajaran ekologi tumbuhan.

\section{METODE}

Jenis penelitian yang dilakukan adalah penelitian dan pengembangan (Research and Development/ $\mathrm{R} \& \mathrm{D}$ ). Pada penelitian ini yang akan menjadi objek penelitian adalah buku ajar bermuatan ekologi tanaman obat tradisional. buku ajar bermuatan ekologi tanaman obat tradisional ini berisi materi Ekologi Tumbuhan untuk mahasiswa pendidikan biologi semester VII. Buku ajar ini memuat petunjuk belajar, kompetensi yang akan dicapai, isi materi pelajaran, informasi pendukung, latihan-latihan, lembar kerja, evaluasi, dan respon atau balikan terhadap hasil evalusi. Desain bahan ajar atau produk yang dibuat terdiri dari beberapa komponen yaitu halaman utama, petunjuk belajar, kompetensi yang akan dicapai, isi materi, informasi pendukung, latihan-latihan, lembar kerja, tugas rumah, evaluasi, kunci jawaban, umpan balik dan daftar pustaka.

Prosedur penelitian R\&D memiliki sepuluh langkah Menurut Sugiyono (2011), yaitu: potensi dan masalah, pengumpulan data, desain produk, validasi desain, revisi desain, uji coba produk, revisi produk, uji coba pemakaian, revisi produk, dan produksi masal. Pada penelitian ini tidak semua langkah dapat dilakukan oleh peneliti karena keterbatasan tenaga dan waktu. Langkah-langkah yang dilakukan peneliti, meliputi menetapkan potensi dan masalah, mengumpulkan informasi, mendesain produk, memvalidasi desain, memperbaiki desain, menguji coba produk, dan revisi produk.

1. Potensi dan Masalah

Penelitian berangkat dari adanya potensi dan masalah, potensi adalah segala sesuatu yang bila didayagunakan akan memiliki nilai tambah. Dalam penelitian ini kecamatan Way Tenong Lampung Barat memiliki keragaman hayati yang melimpah khususnya jenis tumbuhtumbuhan yang beragam yang ternyata beberapa jenis tumbuhan tersebut dapat dimanfaatkan sebagai tanaman obat tradisional, sedangkan masyarakat saat ini banyak yang belum mengetahui jenis tanaman obat tradisional dan sudah jarang masyarakat menggunakan dan menanam tanaman-tanaman obat tersebut di sekitar perkarangan rumah. Dari hasil inventarisasi tanaman obat tradisional yang ada di kecamatan Way Tenong Lampung Barat peneliti akan mengembangkan buku ajar yang bermuatan tanaman obat tradisional yang akan diberikan kepada calon pendidik atau guru yang ada di 
Universitas Muhammadiyah Metro melalui mata kuliah Ekologi tumbuhan.

2. Mengumpulkan Informasi

Informasi jenis tanaman obat diperoleh melalui inventarisasi tanaman obat tradisional melalui pengembangan buku ajar.

3. Desain Produk

Desain produk berupa buku ajar yang meliputi indikator 1) kelengkapan bahan ajar, 2) kelayakan isi, penggunaan bahasa, 3) penyajian materi, dan 4) kegrafisan bahan ajar.

4. Validasi Desain

Praktisi atau pengguna yang dipilih sebagai penilai validasi desain yaitu dua orang dosen Pendidikan Biologi mata kuliah Ekologi Tumbuhan, dan dua orang ahli pembelajaran yang berkompeten di bidang media pembelajaran dan dua orang mahasiswa sebagai prktisi.

5. Perbaikan Desain

Setelah desain produk divalidasi oleh pakar para ahli dan praktisi, maka dapat diketahui kelemahannya, dan selanjutnya kelemahan tersebut dikurangi dan diperbaiki agar produk yang dihasilkan valid.

6. Uji coba Produk

Pengujian dilakukan melalui eksperimen, dengan menggunakan Matching Pretest-Postest Control Group yang dimaksudkan untuk mengetahui efektivitas penggunaan bahan ajar terhadap perubahan kognitif (hasil belajar) mahasiswa.

\section{HASIL}

Tabel 1. Hasil analisis validasi ahli desain buku ajar

\begin{tabular}{c|c|c|c|c}
\hline \multirow{2}{*}{ Aspek } & \multicolumn{4}{|c}{ Hasil Penilaian } \\
\cline { 2 - 5 } Buku Ajar & Tahap 1 & Krite ria & Tahap 2 & Krite ria \\
\hline \multirow{2}{*}{59.23} & $\begin{array}{c}\text { Cukup } \\
\text { Valid }\end{array}$ & 75.38 & Valid \\
\hline
\end{tabular}

Tabe12. Hasil analisis validasi ahli materi buku ajar

\begin{tabular}{c|c|c|c|c}
\hline \multirow{2}{*}{ Aspek } & \multicolumn{4}{|c}{ Hasil Penilaian } \\
\cline { 2 - 5 } Buku Ajar & Tahap 1 & Krite ria & Tahap 2 & Krite ria \\
\hline \multirow{2}{*}{ Buy } & 56 & $\begin{array}{c}\text { Cukup } \\
\text { Valid }\end{array}$ & 75 & Valid \\
\hline
\end{tabular}

Tabel 3 Analisis hasil peniaian mahasiswa

\begin{tabular}{c|c|c}
\hline \multirow{2}{*}{ Aspek } & \multicolumn{2}{|c}{ Hasil Penilaian } \\
\cline { 2 - 3 } & $\begin{array}{c}\text { Rata- } \\
\text { rata }\end{array}$ & Krite ria \\
\hline Buku Ajar & 76.2 & Valid \\
\hline
\end{tabular}

Tabel 4 Rata-rata Masing-masing Kelompok

\begin{tabular}{|c|c|c|c|c|c|}
\hline \multicolumn{6}{|c|}{ Group Statistics } \\
\hline & Kelas & $\mathrm{N}$ & Mean & $\begin{array}{c}\text { Std. } \\
\text { Deviation }\end{array}$ & $\begin{array}{l}\text { Std. Error } \\
\text { Mean }\end{array}$ \\
\hline \multirow{2}{*}{$\begin{array}{l}\text { Hasil } \\
\text { Test }\end{array}$} & A & 30 & .6788 & .24640 & .08213 \\
\hline & $\mathrm{B}$ & 30 & .5716 & .33867 & .06183 \\
\hline
\end{tabular}

Tabe15. Hasil Independent Sample T-test 


\begin{tabular}{|c|c|c|c|c|c|c|c|c|}
\hline & & \multicolumn{7}{|c|}{ Inde pendent Samples Test } \\
\hline & & \multicolumn{2}{|c|}{$\begin{array}{c}\text { Levene's Test } \\
\text { for Equality of } \\
\text { Variances }\end{array}$} & \multicolumn{5}{|c|}{ t-test for Equality of Means } \\
\hline & & $\mathrm{F}$ & Sig. & $\mathrm{t}$ & $\mathrm{df}$ & $\begin{array}{l}\text { Sig. (2- } \\
\text { tailed) }\end{array}$ & $\begin{array}{c}\text { Mean } \\
\text { Difference }\end{array}$ & $\begin{array}{l}\text { Std. Error } \\
\text { Difference }\end{array}$ \\
\hline \multirow[t]{2}{*}{$\mathrm{y}$} & $\begin{array}{l}\text { Equal variances } \\
\text { assumed }\end{array}$ & 3.570 & $.064^{*}$ & $2.076 * *$ & 58 & $.042 * *$ & .15061 & .07255 \\
\hline & $\begin{array}{l}\text { Equal variances } \\
\text { not as sumed }\end{array}$ & & & 2.066 & 48.126 & .043 & .15061 & .07255 \\
\hline
\end{tabular}

\section{PEMBAHASAN}

\begin{tabular}{llr}
\multicolumn{1}{c}{ Hasil } & \multicolumn{1}{c}{ belajar } & yang \\
dibandingkan & merupakan skor \\
perolehan & (gain) mahasiswa
\end{tabular} berdasarkan selisih dari pos-tes dan pre-tes yang telah dinormalisasi (gain normalize). Pengujian dilakukan pada kelompok subjek penelitian yang secara teoritis dikategorikan setara dan homogen. Analisis perhitungan uji- $\mathrm{t}$ hasil belajar sebelum dan sesudah menggunakan buku ajar tanaman obat Mahasiswa di suku Semendo Kecamatan Way Tenong Lampung Barat dihitung dengan menggunakan SPSS dan dapat dilihat pada Tabel 4.

Berdasarkan Tabel 4 terlihat jumlah data baik dari kelompok variabel perlakuan (treat) maupun dari kelompok variabel non perlakuan adalah sama, yaitu masing-masing 30 mahasiswa. Rata-rata (mean) kelompok pelakuan adalah 0,68 (peningkatan tinggi) dan data kelompok non perlakuan 0,57 (peningkatan sedang). Data yang dianalisis merupakan data gain yang telah dinormalisasi ( $\mathrm{N}$-gain).

Berdasarkan analisis uji kesamaan dua rata-rata tabel 5 didapatkan nilai $\mathrm{t}$ hitung $>\mathrm{t}$ tabel $(2,076>1,70)$, maka Ho ditolak. Kesimpulan ada perbedaan rata-rata hasil belajar melalui buku ajar tanaman obat dengan rata-rata hasil belajar tanpa melalui buku ajar tanaman obat. Sedangkan analisis uji perbedaan dua rata-rata tabel 5 didapatkan nilai $\mathrm{t}$ hitung $>\mathrm{t}$ tabel $(2,076>1,70)$, maka Ho ditolak. Kesimpulan rata-rata hasil belajar mahasiswa melalui buku ajar tanaman obat lebih dari rata-rata hasil belajar mahasiswa melalui proses pembelajaran konvesional.

Tahapan ini dilakukan setelah bahan ajar divalidasi melalui 2 tahapan oleh ahli. Hasil penilaian mahasiswa didapatkan nilai 76.2 penilaian hasil ini jika dikonversikan berdasarkan Riduwan (2008), maka didapatkan kriteria valid dengan batas minimum penilaian $>60$. Uji coba buku ajar tanaman obat ini dilakukan pada mahasiswa pendidikan biologi Universitas Muhammadiyah Metro semester VII. Jumlah mahasiswa yang mengikuti uji coba produk termasuk kelompok kecil karena hanya berjumlah 30 mahasiswa.

Pengujian dilakukan melalui eksperimen, dengan menggunakan Matching Pretest-Postest Control Group yang dimaksudkan untuk mengetahui efektivitas penggunaan bahan ajar terhadap perubahan kognitif (hasil belajar) mahasiswa. Pre-tes adalah tes yang diberikan sebelum pembelajaran dimulai dan bertujuan untuk mengetahui sampai dimana penguasaan mahasiswa terhadap bahan pembelajaran yang akan diajarkan, Pos-tes adalah tes 
yang bertujuan untuk mengetahui perbedaaan akhir siswa setelah pembelajaran dilakukan. Untuk mengetahui ada tidaknya efek dari penerapan buku ajar tanaman obat terhadap kelompok perlakuan, maka diperlukan kelompok non perlakuan (kontrol) sebagai pembanding yang berada pada universitas yang sama. Baik terhadap kelompok perlakuan maupun kontrol, untuk mengukur aspek kognitif, keduanya diberi pretes dan pos-tes. Selisih antara pre-tes dan pos-tes, setelah dinormalisasi (gain normalization), dibandingkan untuk mengetahui ada tidaknya efek dari penerapan buku ajar tanaman obat.

Hasil uji coba didapatkan bahwa rata-rata hasil belajar mahasiswa melalui pemberian buku ajar tanaman obat lebih dari rata-rata hasil belajar mahasiswa melalui proses pembelajaran konvensional, hal ini sesuai dengan hasil analisis data uji-t menggunakan SPSS 16.0. Situmorang (2013) Buku ajar dapat menolong siswa untuk mencapai kompetensi sesuai tuntutan kurikulum karena menuntun siswa belajar kimia secara efisien sehingga terjadi pergeseran pembelajaran dari teacher centre learning menuju student centre learning. Sama halnya dengan Hafiz (2015), pengembangan buku ajar yang di hasilkan dapat meningkatkan hasil belajar kelas perlakuan yang menggunakan produk buku ajarnya.

Pemberian buku ajar tanaman obat yang dikembangkan berdasarkan inventaris langsung dari daerah di suku Semendo Kecamatan Way Tenong Lampung Barat secara tidak langsung memberikan informasi yang menyajikan fakta mengenai penyebaran jenis tanaman obat, jenisjenis tanaman obat, mengetahui tanaman obat yang dapat dimanfaatkan untuk produksi, hal ini selain membekali mahasiswa memperoleh informasi yang akurat mengenai tanaman obat, juga dapat meningkatkan kognitif siswa, karena belajar melalui fakta-fakta yang ada lebih menarik dan memberikan pengalaman yang lebih bermakna. Pemberian fakta langsung juga mengarah pada pendekatan scientific. Scientific pertama kali diperkenalkan melalui ilmu pendidikan Amerika pada abad ke 19, sebagai penekanan pada metode laboratorium formalistic yang mengarah pada fakta-fakta ilmiah (Rohadi:2005). Selanjutnya mahasiswa dapat mengembangkan rasa peduli terhadap lingkungan di sekitarnya dengan melakukan pengamatan langsung untuk mendata dan mencari tau mengenai tanaman obat yang ada di sekitar lingkungan mereka. Sesuai dengan pendapat Mulyoto (2013) pendekatan scientific merupakan pendekatan pembelajaran dimana peserta didik diajak untuk melakukan proses pencarian pengetahuan berkenaan dengan materi pelajaran melalui aktivitas sains, untuk menemukan sendiri berbagai fakta, membangun konsep dan nilainilai baru yang diperlukan untuk kehidupannya. Dengan demikian terbukti pemberian buku ajar tanaman obat dapat meningkatkan hasil belajar mahasiswa.

\section{KESIMPULAN}

1. Buku ajar bermuatan ekologi tanaman obat di suku Semendo Kecamatan Way Tenong Lampung Barat pada pembelajaran ekologi tumbuhan teruji layak digunakan baik berdasarkan validasi ahli desain dan materi.

2. Hasil pembuatan buku ajar tanaman obat di suku Semendo $\begin{array}{llr}\text { Kecamatan } & \text { Way } & \begin{array}{r}\text { Tenong } \\ \text { Lampung }\end{array} \\ \text { Barat } & \text { bermuatan }\end{array}$ 
ekologi tanaman obat pada pembelajaran ekologi tumbuhan teruji kepraktiksan melalui penilaian mahasiswa pendidikan biologi Universitas Muhammadiyah Metro semester VII tahun 2016.

3. Buku ajar bermuatan ekologi tanaman obat di suku Semendo Kecamatan Way Tenong Lampung Barat efektif digunakan pada pembelajaran ekologi tumbuhan melalui uji t bahwa rata-rata hasil belajar mahasiswa melalui pemberian buku ajar tanaman obat lebih dari rata-rata hasil belajar mahasiswa melalui proses pembelajaran konvensional.

\section{SARAN}

Produk pengembangan buku ajar tanaman obat harus diujicobakan di kelas dengan skala lebih besar untuk mendapatkan data perbaikan tentang pembelajaran.

\section{DAFTAR PUSTAKA}

Depdiknas. 2008. Panduan Pengembangan Bahan Ajar. Jakarta: Depdiknas.

Hafiz, A. 2015. Pengembangan Buku Ajar Berbasis Alquran dan Hadis. Jurnal Madrasah Ibtidaiyah. Volume 1, Nomor 1, Oktober 2015.

Iskandar. 2003. Kedudukan Anak Tunggu Tubang Dalam Pewarisan Masyarakat Adat suku Semendo di kota Palembang. Thesis Program Pasca Sarjana. Universitas Dipenogoro. Semarang.

Menkes. 2007. Tentang Kebijaksaan Obat Tradisional Indonesia. Keputusan Menteri Kesehatan Republik Indonesia. Nomor 381/MENKES/SK/III/2007. Jakarta
Mulyoto. 2013. Stategi Pembelajran di Era Kurikulum 2013. Jakarta: Putra Karya.

Noor, R., dan S. Zen. 2015. Inventarisasi Tanaman Obot di Masyarakat Suku Semendo di Kecamatan Way Tenong Kabupaten Lampung Barat. Prosiding Seminar Nasional: Transformasi Nilai Nilai Islam dalam Meningkatkan SDM Bangsa Indonesia. Lembaga Penelitian UM Metro. ISBN 978602-74135-0-4

Riduwan. 2008. Variabel-variabel Penelitian. Bandung: Alfabeta.

Rohadi, R. 2005. Pendidikan Sains yang

Humanistik;Memperdayakan

Anak melalui Pendidikan Sains. Yogyakarta: Kanisus.

Situmorang, M. 2013. Pengembangan Buku Ajar Kimia SMA Melalui Inovasi Pembelajaran dan Integrasi Pendidikan Karakter untuk Meningkatkan Hasil Belajar Siswa. Prosiding Seminar Universitas Lampung.

Sugiono. 2012. Metode Penelitian Kuantitatif Kualitatif dan $R \& D$. Bandung: Alfabeta. 